Egyptian Journal of Aquatic Biology \& Fisheries

Zoology Department, Faculty of Science,

Ain Shams University, Cairo, Egypt.

ISSN $1110-6131$

Vol. 23(3): $441-454$ (2019)

www.ejabf.journals.ekb.eg

\title{
Reproductive behaviour of the silver-stripe blaasop; Lagocephalus sceleratus (Gmelin, 1789) from the Mediterranean coast, Egypt.
}

\author{
Mahmoud M. S. Farrag ${ }^{* 1,2}$, Alaa eldin A. K. El-Haweet ${ }^{3}$, Alaa G.M. Osman ${ }^{1,2}$, \\ El-Sayed Kh. A. Akel ${ }^{4}$ and Mohsen A. Moustafa ${ }^{1}$ \\ 1- Faculty of Science, Al-Azhar University (Assiut Branch), Egypt. \\ 2- Department of Ecophysiology and Aquaculture, Leibniz-Institute of Freshwater Ecology and \\ Inland Fisheries, Müggelseedamm 310, 12587 Berlin, Germany \\ 3- College of Fisheries, Technology and Aquaculture. Arab Academy for Science, Technology \\ and Maritime Transportation, Egypt. \\ 4- National Institute of Oceanography \& Fisheries (Alexandria), Egypt. \\ * Corresponding author: m mahrousfarrag@yahoo.com; farrag@igb-berlin.de
}

\author{
ARTICLE INFO \\ Article History: \\ Received: Feb.22, 2019 \\ Accepted: Aug. 28, 2019 \\ Online: Sept. 2019

\section{Keywords:} \\ Lagocephalus sceleratus \\ Mediterranean Sea \\ Egypt \\ Reproductive biology \\ Histology \\ Lessepsian fish
}

\begin{abstract}
In this study, the reproductive biology of the silver stripe blaasop; Lagocephalus sceleratus(Lessepsian pufferfish) from the Mediterranean waters, Egypt was investigated during 2014 using 795 specimens in order to fill the current gap in knowledge of such important species and the relation to its rapid distribution and impact on its new ecosystem. The results revealed that the percentage of males was slightly higher than that of females, representing $52.44 \%$ of all individuals, with a sex ratio of 1:0.91 (M: F). Fish length at first sexual maturity ( $\mathrm{Lm}=50 \%$ maturation) was lower in males $(38.5 \mathrm{~cm})$ than females $(41 \mathrm{~cm})$. The elevation of gonad somatic index (GSI) indicates that the spawning season extends from April to September. The ripe ova diameter was ranged from 0.5 to $0.82 \mathrm{~mm}$, which occurred during the spawning period with a clear one peak towards the last months of spawning. Absolute fecundity increased as the fish grew in length and weight; it ranged from 260288 to 2372931 with an average of $1449522 \pm 720975$. The relative fecundity ranged from 5784 to 32,957 for fish lengths ranging from a group (43-45) to $(70-72 \mathrm{~cm})$, with an average of 24,478 $\pm 10,011$, while it ranged from 698 to $3285 \mathrm{~g}$, with an average of $776 \pm 231 \mathrm{eggs}$ for fish weight range (373 to 722 g). Histologically, this species is considered a totally or unispawner, spawns a synchronous group, and releases the ripe ova in one batch during the spawning season. The present results reflect the successful reproduction and high fecundity, explaining its success and rapid spread of L. sceleratus in its new ecosystem of the Mediterranean Sea companied with the social impact on the fisheries community and probabilities of toxic cases occurrence. This work is recommended to be used in further studies on pufferfish species, which need intensive attention in different scientific fields for various purposes.
\end{abstract}

\section{INTRODUCTION}

The silver-stripe blaasop; Lagocephalus sceleratus (Gmelin, 1789) is the most important puffer fish species and has attracted attention since its migration from the Red Sea to the Mediterranean Sea, creating a critical social impact with its rapid spread across different countries in the Mediterranean Basin (Farrag, 2014). It is currently one 
of the fastest expanding Lessepsian immigrants (Peristeraki et al., 2006) and is a widely distributed species that inhabits the tropical Indian and Pacific Oceans, from which it originates (Nader et al., 2012).

Biological invasions in the Mediterranean basin continue to occur and have become an ecological and economic issue that must be studied and monitored (Bariche et al., 2004; IUCN, 2008; Oral, 2010). On the Egyptian Mediterranean coast, the migrants have been exceeded year after one including both negative and positive effects on the ecosystem (Farrag et al., 2016). In the case of the negative impact, the pufferfish species are among these famous species. According to Farrag et al. (2016); six puffer fishes were identified in the Mediterranean coast of Egypt and namely $L_{-}$- sceleratus (Gmelin, 1789); Lagocephalus suezensis Clark and Gohar, 1953; L.guentheri Miranda Ribeiro, 1915; Lagocephalus lagocephalus (Linnaeus, 1758), Torquigener flavimaculosus Hardy\&Randall, 1983 and Sphoeroides pachygaster (Müller and Troschel, 1848). However, there is a seventh species namely Lagocephalus spadicus, has been mentioned before (El-Haweet et al, 2011) to become seven species. Among them,the population of $L$. sceleratus has expanded along the coast becoming the most common the puffer fish species and the largest one, creating a social impact on the fishing community (El-Haweetet al., 2016 and Farrag et al., 2016). Studies on puffer fishes over worldwide usually have focused on toxicity and biochemistry studies, while there is little available information on their fisheries and biological aspects. In Egypt, particularly for the Mediterranean coast, few studies have been documented (Farrag et al., 2015 a, b; El-Haweet et al., 2016; Farrag et al., 2016). They studied its catch, distribution, growth and fisheries status. The expanding and appearance of species usually depends on its biological behavior such as reproduction, feeding and growth. Casarett and Doull (1975) stated that, the appearance and amounts of toxin in that fishes appear to be related to the reproductive cycle. Moreover, the establishment of data bases on the reproductive parameters leads to a better understanding of observed fluctuations in reproductive output and enhances our ability to estimate recruitment (Kraus et al., 2002). The present work aims to evaluate the reproductive characteristics of $L$. sceleratus in Egyptian Mediterranean waters to fill the current gap in knowledge and to interpret its rapid distribution, impact in its new ecosystem and its potentiality for further toxicological studies.

\section{MATERIALS AND METHODS}

A reproductive biology of L. sceleratus using 795 specimens $(5-83 \mathrm{~cm}$ total length, 1.9-4890 g gutted weight, corresponding to $2.1-5400 \mathrm{~g}$ total weight) was investigated during 2014. The specimens were collected monthly from landing sites along the Egyptian Mediterranean coast ( $34^{\circ} 12^{\prime} 36^{\prime \prime} \mathrm{E}$ and $\left.31^{\circ} 15^{\prime} 00^{\prime \prime} \mathrm{N}\right)$ to $\left(25^{\circ} 08^{\prime}\right.$ $42^{\prime \prime} \mathrm{E}$ and $31^{\circ} 30^{\prime} 00^{\prime \prime} \mathrm{N}$ ) (Fig. 1). The total length (TL) of each fish was measured to the nearest 0.1 centimetre $(\mathrm{cm})$, and the total and gutted weights were obtained to the nearest gram. The weights of gonads and livers were recorded to the nearest milligram (mg). Gonads were preserved in $10 \%$ formalin for fecundity examinations. The following items were studied:the sex ratio was determined as the percentage of males to females (M: F), and the chi-square test at the 0.05 significance level was computed according to Snedecor (1956). Gonadal maturity stages were evaluated and classified according to colour and size in relation to the body cavity using a modified scale version of Nikolsky (1963). The length at sexual maturity (L 50\%) was calculated during the spawning season (Pitt, 1970). The gonadosomatic index (GSI= gonad weight $* 100$ / $\mathrm{W}_{\text {gut }}$ ) was calculated according to Sokal and Rohlf (1969), where $\mathrm{W}_{\text {gut }}$ is the gutted 
weight of the fish (g).Mean egg diameter (= (length of long axis + length of short axis)/ 2) was calculated (Murua et al., 2003) using an ocular micrometre.

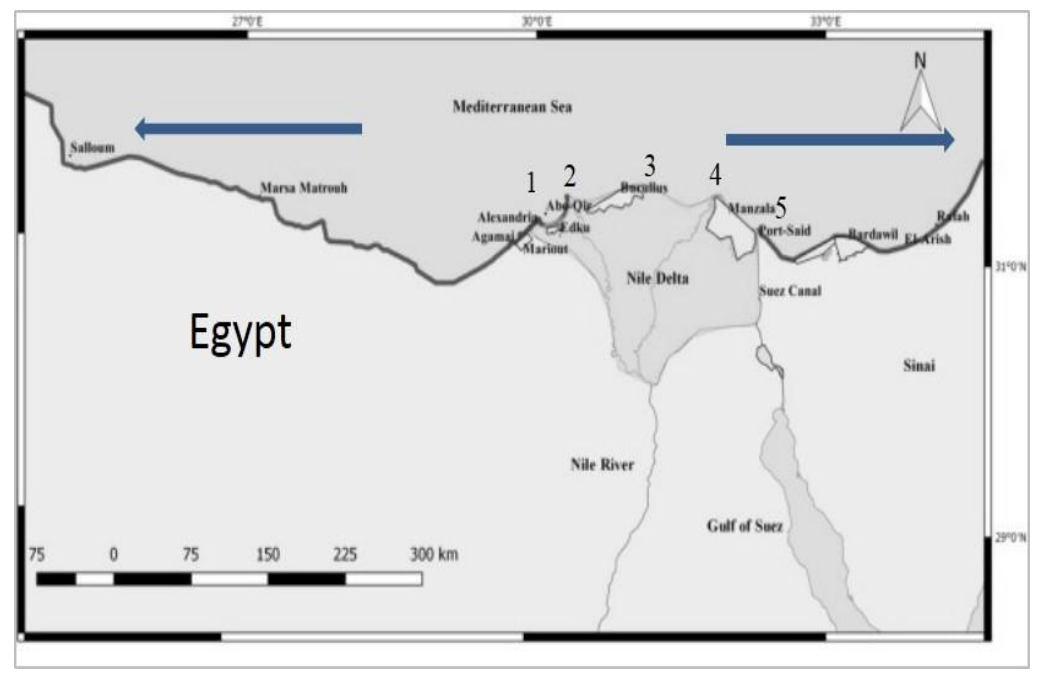

Fig. 1: Study area and collection landing sites along the Egyptian Mediterranean coast: (1) Alexandria (Anfoushy), (2) Abu-Qir, (3) El-Burullus, (4) Ezbet-ElBorg (Damietta) and (5) Port Said.

For histological examination, 60 gonads (36 ovariesand 24 testes) were utilized and finally stained with Harris's haematoxylin and eosin staining protocol (Hunter and Macewicz, 1985). Then, the fish were categorized intodevelopmental stages according to the criteria described by Nikolsky (1963). The oocytes and spermatocytes were measured to the nearest $\mu \mathrm{m}$ using a sensitive ocular micrometre (at $0.01 \mathrm{~mm}$ sensitivity).

Fecundity was estimated using 43 ripe ovaries, and the absolute fecundity was calculated according to Nikolsky (1963): $\mathrm{F}=\mathrm{GW} / \mathrm{w} * \mathrm{X}$, where $\mathrm{F}$ is the absolute fecundity in terms of number, GW is the gonad weight $(\mathrm{g}), \mathrm{w}$ is the mean weight of subsamples and $\mathrm{X}$ is the number of eggs in the sub-sample, while the relative fecundity was calculated as the number of eggs per gram of body weight and $\mathrm{cm}$ of body length. The results were treated statistically using the Microsoft Excel program with a covariance analysis subroutine, and one-way analysis of variance (ANOVA) was also conducted (Statistica, 2007).

\section{RESULTS}

The investigation of $L$. sceleratus with showed that males were more abundant than females (Males (No.408): Females (No. 371)) throughout the year, representing $52.44 \%$ of the total fishes, with a sex ratio of 1:0.91. The chi-square statistic $\left(\chi^{2}\right)$ was $1.76(\mathrm{P}<0.05)$, indicating a significant difference between the sexes. The highest ratios were observed for the small-sized groups $(\mathrm{M}: \mathrm{F}=1: 1.4 ; 1: 1.9,1: 2.8$ and $1: 1.2$ for groups of 13-16, 17-20, 21-24, and 29-32 TL, respectively), in which females were abundant, in addition to a ratio of 1:2 for the large-length group $(69-72 \mathrm{~cm})$, while males were abundant in the moderate- to largest-sized groups. Parity was observed for the size groups of 65-68 and 73-76 cm TL (Fig. 2a). In terms of month, males were higher in occurrence than females during most months of the year except for January (1:1.56), March (1:1.19), August (1:1.09) and December (1:1.28), in which females were higher in occurrence than males (Fig. 2b). 

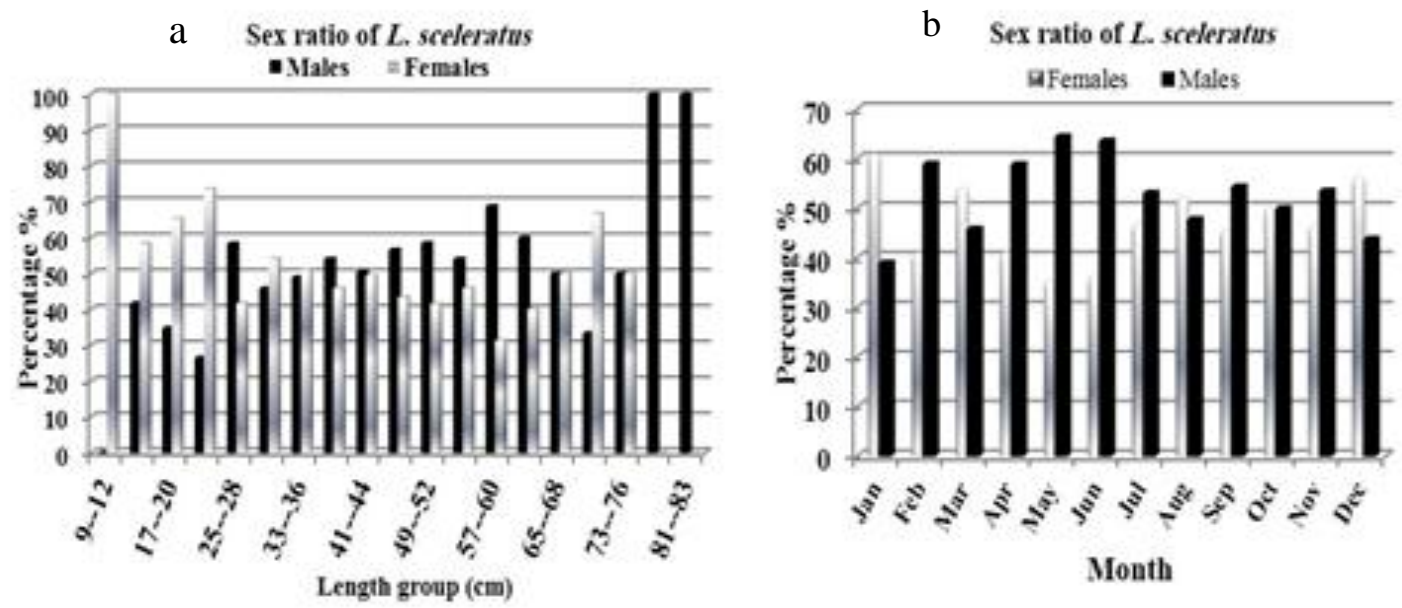

Figs. (2a,b): Variation in the sex ratio of L. sceleratus according to length and month.

Maturity was classified into seven stages, including thread-like, immature (virgin), maturing (developing virgin and recovering spent), nearly ripe, fully ripe, VI-spawning (running) and VII-spent stages. The ripe and spent stages, as important indicators ofthe start and end of the spawning season, are shown in Fig. (3).Regarding the monthly distribution of these stages (Figs. 4a,b), immature members of both sexes were found in all months.
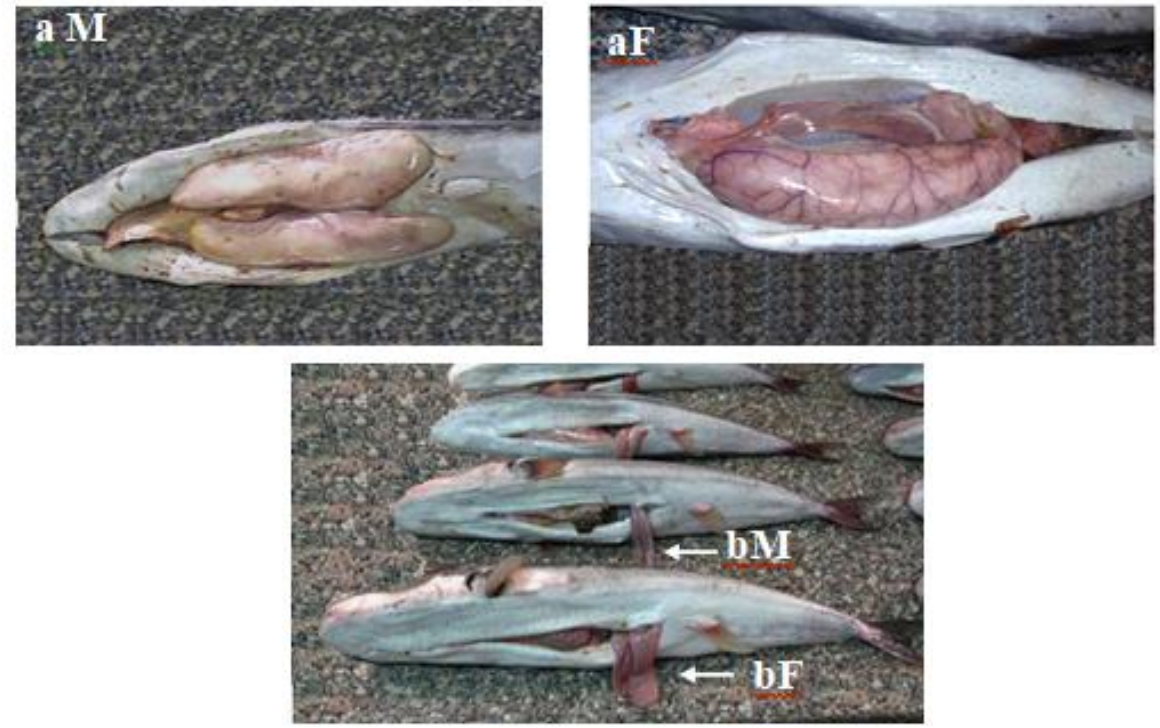

Fig. (3a,b): Maturity stages for males (M) and females (F) of L. sceleratus, showing indicator stages (a: ripe, b: spent).
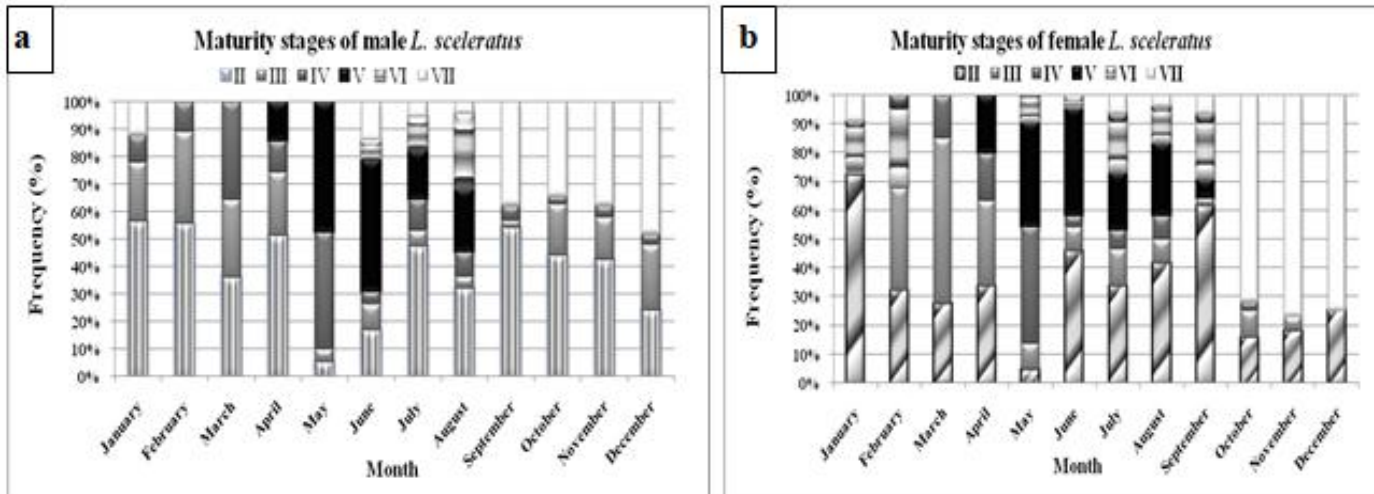

Fig. (4a,b): Monthly distribution of maturity stages of L. sceleratus ( $\mathrm{a}$, males \& b. females). 
Individuals with ripe gonads appeared in April, accounting $13.95 \%$ and $20.00 \%$ of males and females respectively, while they disappeared in October, revealing a prolonged spawning season from April to September with a peak in June for both sexes. The spawning (running) stage began in May and extended to late October, and the spent stage extended to January for males and to February for females. The length at first sexual maturity (L50\% orL $\mathrm{L}_{\mathrm{m}}$ ) was $38.5 \mathrm{~cm}$ for males and $41 \mathrm{~cm}$ for females (Fig. 5).

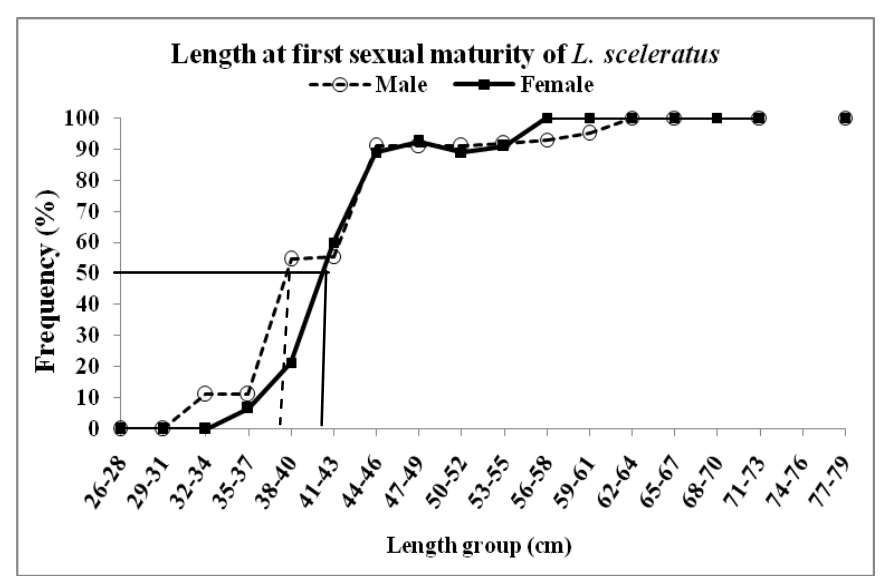

Fig. 5: Length at first sexual maturity $\left(\mathrm{L}_{\mathrm{m}}\right)$ for males and females of L. sceleratus.

The GSI over the year showed a gradual increase from April for both sexes towards the following monthes, and a sharp decrease was observed in October $(0.207 \pm 0.161$ and $0.575 \pm 0.293)$ for males and females, respectively. This gave the same trend of spawingn from April and ends in September. The peak of the GSI occurred in

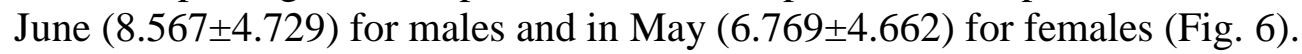

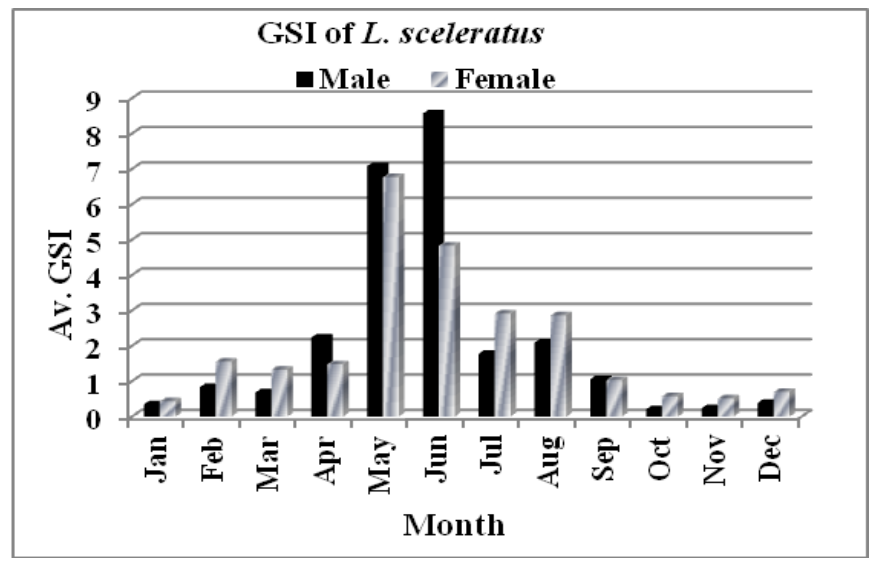

Fig. 6: Monthly variation in the gonadosomatic index (GSI) for males and females of L. sceleratus.

The frequencies of different egg diameters during the spawning season are shown in (Fig.7), they were differentiated based on maturation size into two groups. The first group included immature (transparent) eggs $(0.02$ to $0.16 \mathrm{~mm})$, and the second group comprised mature eggs, including yolky and ripe eggs with a size range of 0.16 to 0.82 $\mathrm{mm}$. The trend of egg diameter showed an increase towards the largest size group from April to September, with the largest range in May $(0.16$ to $0.76 \mathrm{~mm}$, with an average of $0.45 \pm 0.24 \mathrm{~mm})$. After that, this range started to be narrow at the larger egg size group, clearly forming one peak with a maximum average of $0.53 \pm 0.18 \mathrm{~mm}$ in September. The fecundity increased as the increase in length and weight. Absolute fecundity ranged 
from 260288 eggs at the length group $(43-45 \mathrm{~cm})$ and fish weight $(698 \mathrm{~g})$ to 2372931 eggs at the length group $(70-72 \mathrm{~cm})$ and fish weight $(3285 \mathrm{~g})$, with totally an average of $1449522 \pm 720975$ eggs. While, the relative fecundity ranged from 5784 to 32957 eggs per length for fish length groups from 43-45 to 70-72 cm, with an average of $24478 \pm 10011$. For the relative fecundity per weight $(\mathrm{g})$, it is ranged from 373 to $722 \mathrm{~g}$ at the fish weights from 698 to $3285 \mathrm{~g}$ for the, with an average of $776 \pm 231$ eggs.
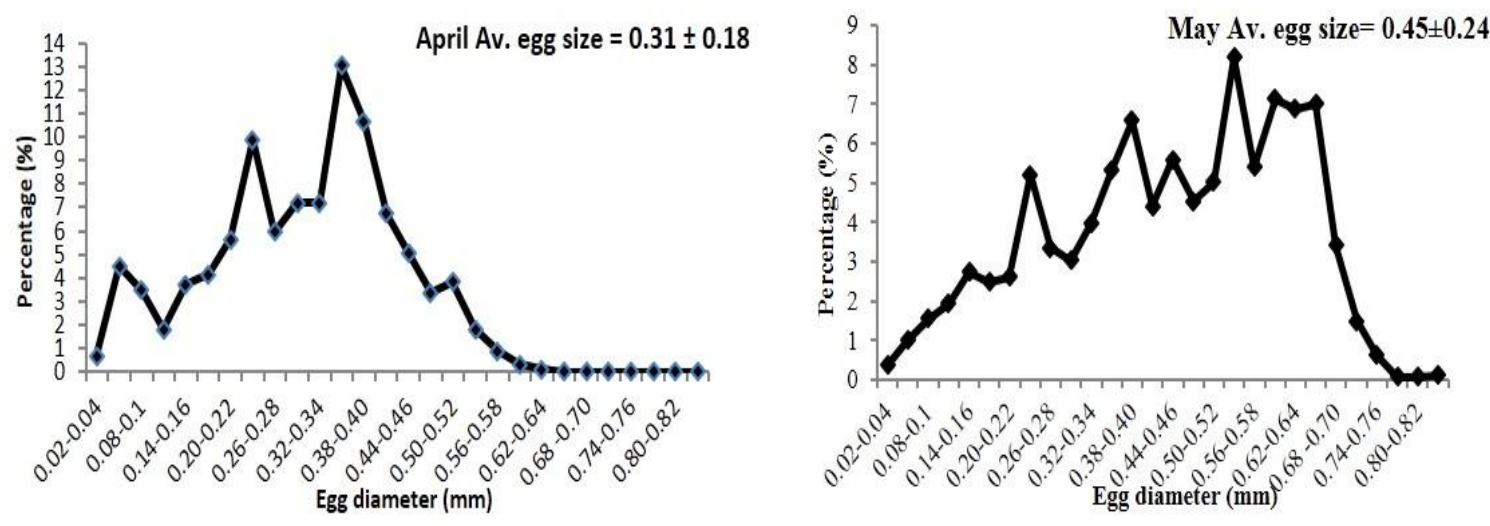

June Av. egg size $=0.50 \pm 0.27$
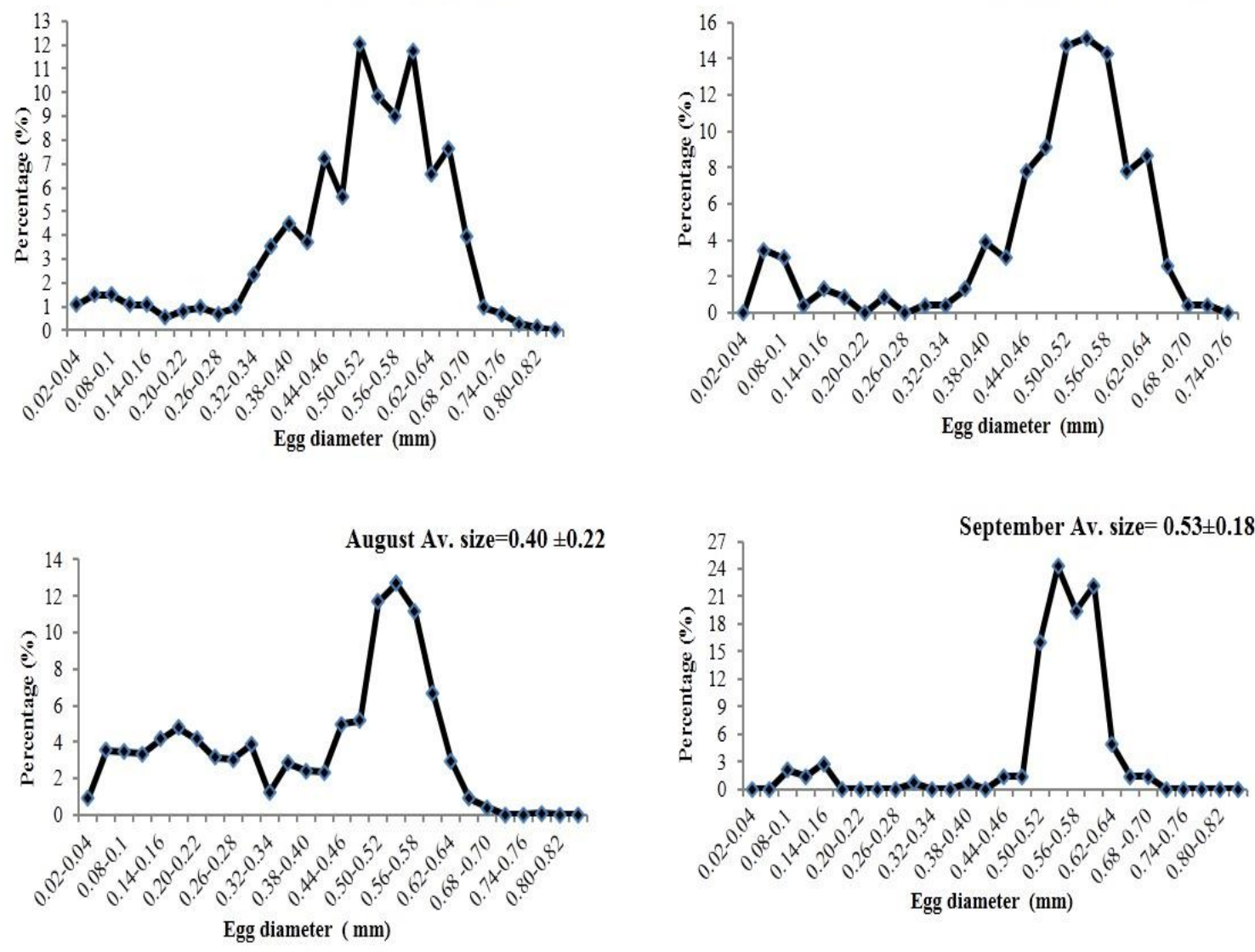

Fig. 7: Frequency distribution of the ovum diameter in L. sceleratusfrom Egyptian Mediterranean waters during the spawning season. 
Histologically, oogenesis showed the highest activity during the period from April to September, and the developmental stages throughout the year could be distinguished into seven stages (immature, mature, vacuolization, yolk deposition, ripening, spawning and spent stages): (I) The immature stage showed thedominance of small, rounded presynaptic cells or oogonia (oog) $(6$ to $12 \mu)$ that were found either solitarily or in small nests; such cells increased in diameter (16 to $44 \mu)$ to form polygonal primary oocytes (Po) with large spherical nuclei $(8$ to $12.5 \mu)$, and their membranes were not yet differentiated. The primary oocyte slightly increased to be more obvious as a secondary oocyte (So) within the range of 32 to $56 \mu$, its nucleus increased in size to $24 \mu$, and the nucleoli varied from 2 to $4 \mu$ (Fig. 8a). This stage was dominant during December and January. (II) The mature stage was the dominant in late January, February and early March: the oocytes were polygonal or hexagonal cells $(22 \mu$ to $65 \mu)$ with a nucleus of $7.5 \mu$ to $26 \mu$ that contained scattered nucleoli (1 to 13 in number). Few small, bright, rounded spots (yolky nucleolus (Yn)) were observed in the cytoplasm by the end of this stage (Fig. 8b); the oocyte was surrounded by a thin follicular epithelium (FE) of 0.7 to $1.5 \mu$ in thickness. (III) The vacuolization stage was recorded in late February and March, with a peak in February. At this stage, vacuoles $(\mathrm{V} ; 4$ to $14 \mu$ ) were observed and arranged in one or two or several rows in the cytoplasm of the oocyte. The oocytes ranged from 65 to $210 \mu$ in diameter with a nucleus of 26 to $60 \mu$. The FE became more conspicuous (2.8 thickness) with an additive layer of zona radiata (ZR) (approximately $35 \mu$ ), and the inner cortical alveoli (CA) had not yet appeared (Fig. 8c). Both the mature and vacuolization stages are considered previtellogenic stages. (IV) The yolk deposition stage was dominant from May to July and was characterized by scattered yolk granules $(5-10 \mu)$ with vacuoles $(4-8 \mu)$ in the cytoplasm of theoocytes. These oocytes (390 to $650 \mu$ ) contained nuclei (40 to $110 \mu$ ) and were enveloped by ZR ( 8 to $14 \mu$ thickness), while the FE ranged from 2 to $5 \mu$ in thickness. Yolk granules began to liquefy, and the nucleus almost appeared as an amoeboid shape. The inner CA also began to appear (Fig. $8 d)$.

(V) The ripening stage dominated the spawning months from April to September, with a peak in July and August. The oocytes increased in size (620 to $750 \mu)$ with a nucleus $(100$ to $120 \mu)$ that appeared intermingled with the cytoplasm and migrated towards the animal pole. The vacuoles reached $20 \mu$ and mixed with the liquefied yolk granules (Fig. 8e).The oocyte membrane had three layers: FE with 4-8 $\mu$ thickness, ZR with 18 to $38 \mu$ thickness and inner CA. Both the yolk deposition and ripening stages are considered vitellogenic stages. (VI) The spawning stage passed through a transitional stage to the spent stage over a short period of time, and the ripe oocytes appeared to be liquified withno nucleus as preovulatory oocytes (Pre.ov) that will be discharged from the ovary (Fig. 8f). (VII) The spent stage involved empty follicles (EFs) as postovulatory oocytes, which combine with the residual eggs undergoing atresia (atretic oocytes (AOs)); the ZR layer became enlarged (38 to $68 \mu$ ), and the wall of the ovary ranged from 200 to $320 \mu$ in thickness (Fig. 8g). The cytoplasmic yolk underwent phagocytosis, resorbed, and disappeared and the yolk vesicles gradually became empty vacuoles (hydrated oocytes). This stage was observed from June to January.

The spermatogenesis process in males passed with through five stages: (I) The immature stage involvedseminiferous lobules filled with rounded spermatogonia (Spg) $(8 \mu$ to $14 \mu$ ) distributed along the lobules with a small number of primary spermatocytes (PS) and few secondary spermatocytes (SS) (Fig. 9a). They had spherical nuclei with distinguishable nuclear membranes. 

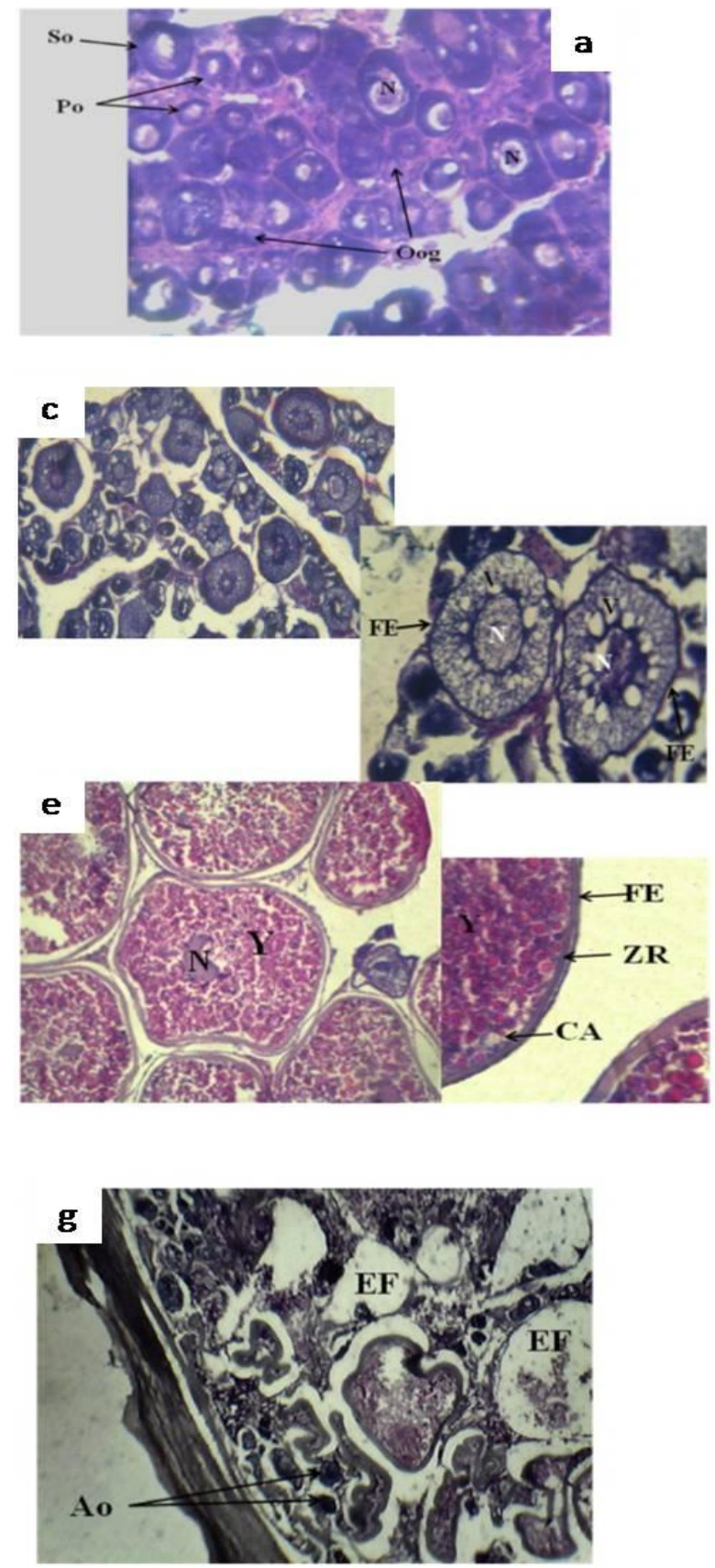

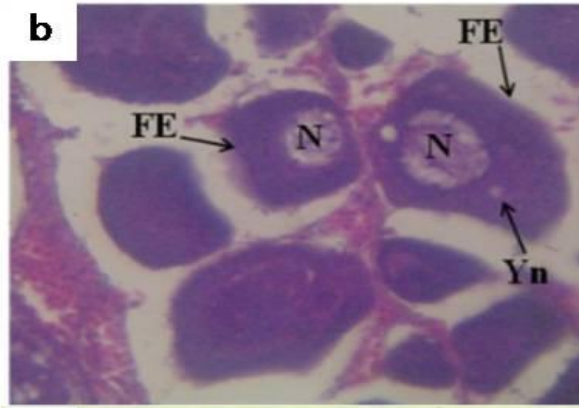

d
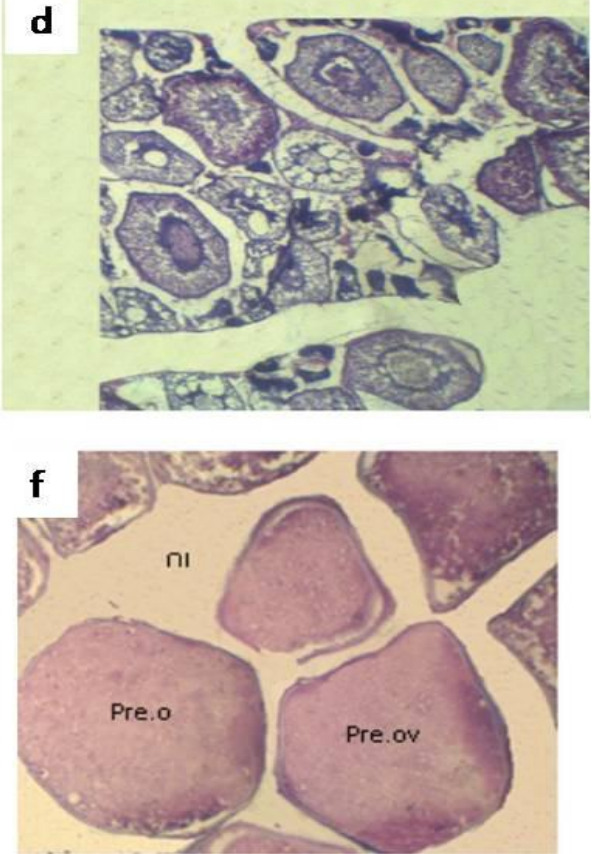

Fig. 8: Oogenesis process showing the immature (400x), mature (a: 100x, b: magnified at 400x), vacuolization (a:100x, b: magnified at 400x), yolk deposition (a:100x, b: magnified at 200x), ripening (100x, 200x and 400x, respectively), spawning (200x), and spent (200x) stages stained with haematoxylin and eosin (H\&E). Oogonia (oog), primary oocyte (po), secondary oocyte (so), nucleus $(\mathrm{N})$, follicular epithelial layer (FE), yolky nucleolus (Yn), vacuoles $(\mathrm{V})$, yolk droplets (Y), zona radiata (ZR), cortical alveoli (CA), preovulatory oocytes (Pre.ov), ovarian lumen (OL), atretic oocyte (AO), empty follicle (EF), post-ovulatory oocytes (Pos. o)and new generation of cytoplasmic growth cells (cg).

(II) During the mature stage, the primary spermatocytes (PS) (from 4 to $6 \mu$ ) and the secondary spermatocytes (SS) (from 3 to $5 \mu$ ) increased in number (smaller in diameter than the spermatogonia) with a few clusters of spermatids (SPD) (Fig. 9b). This stage was observed from January to March. (III) Nearly ripe testes showed more active spermatogenesis processes during late March, April, and May (Fig. 9c). Spermatid cells ( 2.5 to $3.5 \mu$ ) were dominant, with few spermatozoa ( 1 to $1.5 \mu$ ) in the lobules. (IV) The ripening stage was observed from April to August as an indicator ofthe spawning period. 
The seminiferous lobules of the testis were filled with spermatozoa ( $1 \mu$ to $1.5 \mu$ diameter) that are prepared to be discharged out of the testis.At this stage, a remarkable quantity of spermatids, few spermatogonia, and primary and secondary spermatocytes were also observed. The seminiferous lobules were separated by interlobular connective tissues, which were clearly much thinner than they were during the previous stage (Fig. 9d). (V) During the spawning-spent stage, the sperm cells were discharged from the seminiferous lobules, which inturn decreased in size. At this time, the testes empty their seminiferous lobules of sperm and become spent, except for some residual spermatozoa that were apparently resorbed (Figs. ea, eb). Newly generating spermatogonia were recorded at the periphery of many lobules. This stage was recorded in most spawning months and continued until October, November, December and early January to form a quiescent period (Rest).
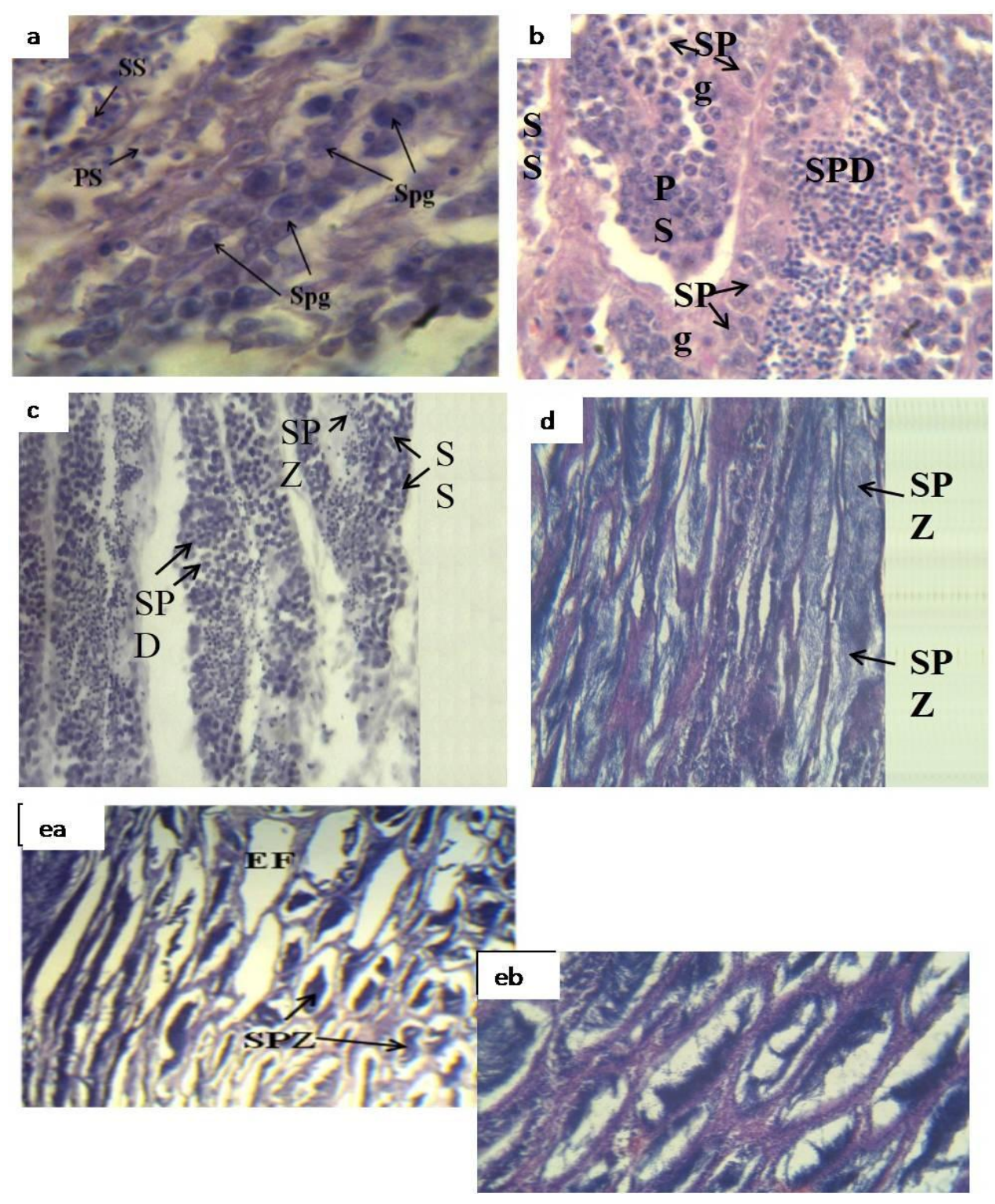

Fig. 9: Testes of L. sceleratus.a: immature stage (1000x), b: mature (1000x), nearly ripe (400x), and ripening (100x) stages and spawning \& spent stages (a: 100x, b: 200x) (H\&E). Seminiferous lobules filled with spermatogonia (Spg), primary spermatocytes (ps), secondary spermatocytes (ss), spermatids (SPD), spermatozoa (SPZ), and emptyfollicles (EF). 


\section{DISCUSSION}

The present study is a new report of the reproductive behaviour of L. sceleratus in Egyptian Mediterranean Waters; it is an attempt to interpret the rapid spread of this species. The overall sex ratio (M:F) throughout the study period was found tobe 1:0.91, with an abundance of males $(52.44 \%)$ among the total fishes. This trend was in agreement with that shown by Aydin (2011) in Turkey. However, it differs from those reported by Sabrah et al. (2006) in the Red Sea, which was 1:1.3, and Boustany et al. (2015) in Lebanon. This difference may be related to the difference in the availability of the two sexes during fishing and the spatial segregation of the sexes, likely a feeding behaviour, when baited gear is used, in accordance with Mendonca et al. (2006). FehriBeduiand and Gharbi (2008) suggested that natural mortality may be affected by the sex ratio and that the higher abundance of certain individuals may be related to high vulnerability to fishing gear.The variability in the sex ratio is also related to length at maturity. The present data show that before the onset of first sexual maturity $(38 \mathrm{~cm})$, more females than males are caught, and males became the dominant sex after this point. This finding was observed by Rousou et al. (2014) and is consistent with White et al. (1998).

The gonad maturity stages, particularly the ripe stages throughout the year, reflected the prolonged spawning season of L. sceleratus from April to September. This evidence somewhat agrees withthe results of Sabrah et al. (2006); Aydin (2011); Rousou et al. (2014) and Boustany et al. (2015). The appearance of some spent characters during the spawning season indicates that many individuals finished their breeding period and that this species completely spawns once. The observation of ripe stages coincided with an increase in the GSI, which is used as an indicator of reproductive condition and spawning time in fishes, as stated by Plaza et al. (2007). This confirms that the spawning season occurred during spring and summer, as indicated previously by the distribution of maturity stages. This finding was similar to those obtained by Sabrah et al. (2006); Peristeraki et al. (2010); Aydın (2011); Rousou et al. (2014) and Boustany et al. (2015). In addition, the GSI for both sexes presented a unimodal curve, indicating that this species spawns only one time per year, in agreement with previous findings.

During the spawning season, the $\mathrm{L}_{\mathrm{m}}$ was $38.5 \mathrm{~cm}$ for males and $41 \mathrm{~cm}$ for females. These values were slightly less than those obtained by Sabrah et al. (2006) $(42.1 \mathrm{~cm}$ and $43.3 \mathrm{~cm}$ for males and females, respectively). However, they were higher than that obtained by Kalogirou (2013) (36 cm for the two sexes combined). Boustany et al. (2015) found a $\mathrm{L}_{50}$ value for the same species from Lebanon of $40 \mathrm{~cm}$ for all specimens, in agreement with the present values if the mean for males and females combined is considered. The differences in estimates may be related to the environmental conditions (e.g., temperature), as phenotypic flexibility occurs in fish, and the environmental conditions may thus affect their size at maturity. This finding agrees with the results of Pyper et al.(1999). In addition, the differences in estimates may also be due to the variation in the number of specimens, length range and habitats. The finding of differencesindicates that the trend of decrease in the $\mathrm{L}_{\mathrm{m}}$ from the south (Red Sea) to the north (Mediterranean from Egypt and then from Rhodes) may be related to favourable conditions, particularly food availability in subtropical regions to temperate zones.

Ovum diameter provides evidence regarding the duration of spawning (prolonged or short) and its mode in terms of whether the members of the species are incomplete spawning mode (unimodal spawners) or partial spawning mode (Yoshida, 1966; Farrag, 2010). The egg diameter in the current study increased in the largest size group from April to September, and the distributionbecame narrow, clearly forming one peak, with a 
maximum average of $0.53 \pm 0.18 \mathrm{~mm}$ in September, which is the last month in the spawning period. These results reveal that these fish release their ova in one batch and show a complete spawning mode (unimodal spawners). This finding may lead to the conclusion that this fish has determinate fecundity. The ovum diameter found in the present study (from 0.16 to $0.82 \mathrm{~mm}$ for mature ova and from 0.02 to $0.16 \mathrm{~mm}$ for immature ova) was less than that ( 385 to $717 \mu \mathrm{m}$, with a mean of $640 \pm 41 \mu \mathrm{m}$ in June) reported by Aydin (2011). These differences may be attributed to the length range of specimens and their number, the duration of the spawning season and fecundity, as indicated by Bonislawska et al. (2001).

The absolute fecundity of L. sceleratus found in the present study increased with increasing length and weight, in accordance with Schmitt and Skud (1978). The relative fecundity also showed a slight increase with increasing length, while it showed fluctuations combined with adecrease, particularly amongthe fish groups with the largest weight with increasing gutted weight. This may be attributed to the presence of individual variation in wellbeing, which may cause fluctuations in fecundity in relation to weight, as indicated by Oso et al. (2011). Moreover, this also may indicate that the oldest fishes had a relative fecundity lower than that of younger mature individuals. These results regarding relative fecundity were lower than those obtained by Aydin (2011) in Turkish waters. This difference may be attributed to the use of thetotal body weight by Aydin (2011) instead of the gutted weight, which was used in the present work. The total egg number per female decreased over the spawning period; this characteristic feature of a species with determinate fecundity was also mentioned by Greer-Walker et al. (1994). This immigrant species with determinate fecundity produceda large number of ova, indicating that this species is able to establish itself well in new habitats and is predicted to increase in abundance.

Histologically, the oogenesis process observed in the present study showed that the larger mature oocytes are surrounded by differentiated FE layers; this indicates the synthesis of sexual steroids, in agreement with the observations of Herrera et al. (1988) in other teleosts.

The presence of vacuolated oocytes (from late January to March), as an indicator of previtellogenesis, indicates that the females will spawn in the following season, as mentioned by Saborido- Rey and Junquera (1998). The presence of yolky oocytes duringthe ripening stage(April to September) illustratesthe occurrence of a prolonged spawning time with an increase in the GSI, in accordance with the macroscopic observation of the ripening stage. From another point of view, the presence of nearly the same-sized oocytes at the same developmental stage in the same ovary indicates that $L$. sceleratus spawns only once (complete mode of spawning) as a synchronous group with determinate fecundity. This trend was observed by Wallace \& Selman (1981) and Hesp et al. (2004) in other fishes. The spent characters were observed in late January among many individuals showing asmall number ofvacuoles and yolky oocytes at the spawning stage, even after finishing with the unimodal mode of spawning. This may cause confusion regarding the end of the spawning period, but this finding may be attributed to the fact that some females had residual eggs left in their ovaries immediately after spawning. This result is in agreement with Dahle et al. (2003). Moreover, this finding could be considered to be among the factors affecting stock variability from one year to another,as the remaining oocytes affect fecundity, which affects stock biomass, as indicated by Murua et al. (2003).

The spermatogenesis cycle passed through several stages, as observed in other teleost species by Assem (2003); Zaki, et al. (2005) and Farrag (2010). The presence of at maximum two types of spermatocytes (spermatids and spermatozoa) as dominant 
spermatocytes during the spawning season indicates a complete spawning mode with a synchronous group of germ cells within the testicular cysts. This result is in accordance with the results for females, indicating that both males and females of L. sceleratus have the same behaviour. The quiescent period perceived before the new cycle began was observed amongnearly all mature individuals andoccurred overa short time from late December to late February. In conclusion, the finding of high fecundity should be taken in consideration among the reasons for the rapid spread of this species and to develop measures to mitigate its effects, as the invasion of this species and the toxins it produces have negative impacts on fisheries, society and public health. Additionally, according to Casarett and Doull (1975), the appearance and amounts of toxin produced by this fish appear to be related to the reproductive cycle and to be greatest just before spawning. Therefore, the observed unimodal mode of spawning may provide information for predicting the presence of nontoxic individuals even during the spawning season, which is the common time when high toxicity is observed amongsuch species, confirming the importance of studies regarding the reproductive cycle of organisms in many scientific fields.

\section{REFERENCES}

Assem, S. S. (2003). The reproductive biology, histological and ultrastructure characteristics of ovaries of the female pelagic fish Pagellus erythrinus from the Egyptian Mediterranean Sea. Egypt. German Soci. Zool., 31c:195-215.

Aydin, M. (2011). Growth, reproduction and diet of pufferfish (Lagocephalus sceleratus Gmelin, 1789) from Turkey's Mediterranean Sea coast. Turkish J. Fish. Aquat. Scie., 11: 589-596.

Bariche, M.; Letourneur, Y.and Harmelin-Vivien, M. (2004). Temporal Fluctuations and settlement patterns of native and Lessepsian herbivorous fishes on the Lebanese coast (Eastern Mediterranean). Envi. Biol. Fishes, 70: 81-90.

Bonislawska, M.; Formicki, K.; Korzelecka-Orkisz, A.;Winnicki, A.et al. (2001): Fish egg size variability: biological significance. Electr. J. Polish Agri. Univ. Fish. (EJPAU), 4 (2):1-15.

Boustany, L.; EL Indary, Sh. and Nader, M. (2015). Biological characteristics of the Lessepsian pufferfish Lagocephalus sceleratus (Gmelin, 1789) off Lebanon. Cah. Biol. Mar., 56:137-142.

Casarett, L. J. and Doull, M. D. Y. (1975). Toxicology (the basic science of poisons). Macmillan publishing Co. Inc. New York. P. 573-580.

Dahle, R.; Taranger, G. L.; Karlsen, Q.; Kjesbu, O. S. and Norberg, B. (2003). Gonadal development and associated changes in liver size and sexual steroids during the reproductive cycle of captive male and female Atlantic cod (Gadusmorhua L.). Compar. Biochemist. Physiol., (A) 136: 641-653.

El-Haweet, A. A. K.; Farrag, M. M. S.; Akel, E. Kh. A. and Moustafa, M. A. (2016). Puffer Fish Catch in the Egyptian Mediterranean Coast "The Challenged Invaders".International Journal of Ecotoxicology and Eco Biology, 1(1): 13-19.

El- Haweet, A.; Fishar, M. R.; Geneid, Y. and Abdel-Moula, E. (2011): Assessment of fisheries and marine biodiversity of Sallum Gulf, Egypt. International Journal of Environmental science and Engineering (IJESE), 1: 21-34.

Farrag, M.M.S.; El-Haweet, A. A. K.; Akel, E.Kh.A.and Moustafa, M. A. (2015a): Stock Status of Puffer Fish Lagocephalus sceleratus (Gmelin, 1789) Along the Egyptian Coast, Eastern Mediterranean Sea. American Journal of Life Sciences. Special Issue: New Horizons in Basic and Applied Zoological Research., 3(1-6): 83- 
93.

Farrag, M. M. S.; Soliman, T.B.H.; Akel, E. Kh. A.; Elhaweet, A.A.K. and Moustafa, M. A. (2015b): Molecular phylogeny and biometrics of lessepsian puffer fish Lagocephalus sceleratus (Gmelin, 1789) from Mediterranean and Red Seas, Egypt. Egyptian J. Aquat.Res., 41:323-335. DOI: 10.1016/j.ejar.2015.08.001

Farrag, M. M. S. (2014). Fisheries and Biological studies on Lessepsian pufferfish, Lagocephalus sceleratus (Gmelin, 1789) (Family: Tetraodontidae) in the Egyptian Mediterranean Waters. Ph.D, Thesis, Fac. Sci., Al-Azhar Univ., (Assuit), Egypt.

Farrag, M. M. S.; El-Haweet, A. A. K.; Akel, E. Kh. A. and Moustafa, M. A. (2016). Occurrence of puffer fishes (Tetraodontidae) in the eastern Mediterranean, Egyptian coast - filling in the gap. BioInvas. Records, 5 (1): 47-54 DOI: http://dx.doi.org/10.3391/bir.2016.5.1.09

Fehri-Bedoui R. and Gharbi H. (2008). Sex-ratio, reproduction and feeding habits of Pomadasys incisus (Haemulidae) in the Gulf of Tunis. Acta Adriat., 49(1): 5-19.

Greer Walker, M.; Witthames, P. R. and Bautista de los, S. I. (1994). Is the fecundity of the Atlantic mackerel (Scomber scombrus: Scombridae) determinate?. Sarsia, 79: 13-26

Herrera, G.; Butos-obregon, E. and Balbontin, F. (1988). Morphological aspects of gonadal maturation in the Hake, Merluccius gayigayi, R. V. Biol. Mr. Valparaiso., 24 (1): 55-71.

Heps, S. A.; Potter, I. C. and Hall, N.G. (2004). Reproductive biology and protandrous hermaphroditism in Acanthopagrus latus. Environ. Biol. Fishes, 70: 257-272.

Hunter, J. R. and Macewiez, B. J. (1985). Measurement of spawning frequency in multiple spawning fishes.In Lasker. R. (ed.), An egg production method for estimating spawning biomass of pelagic fish: Application to the northern anchovy,. NOAA Tech. Rep. NMFS, 36: 79-94.

IUCN - ISSG, (2008). Aliens, 27: 1-30.

Kalogirou, S. (2013). Ecological characteristics of the invasive pufferfish Lagocephalus sceleratus (Gmelin, 1789) in Rhodes, Eastern Mediterranean Sea. A case study. Medit. Mari. Sci.,14 (2): 251-260.

Kraus, G.; Tomkiewicz, J. and Koster, F. W. (2002). Egg production of Baltic cod in relation to variable sex ratio, maturity and fecundity. Canad. J. Fish., and Aquatic Sci., 59: 1908-1920.

Mendonca, A.; Isidro, E.; Menezes, G.; Pinho, M. R.,; Melo, O. and Estacio, S. (2006). New contribution to the reproductive features of blue mouth Helicolenus dactylopterus dactylopterus from the northeast Atlantic (Azores Archipelago). Scienta Mari., 70: 679-688.

Murua, H.; Kraus, G.; Saborido-Rey, F.; Witthames, P. R., Thorsen, A. and Junquera, S. (2003). Procedures to Estimate Fecundity of Marine Fish Species in Relation to Their Reproductive Strategy. J. Northwest Atlantic Fish. Sci., 33: 33-54.

Nader, M.; Indary S. and Boustany L. (2012). FAO EastMedThe Puffer Fish Lagocephalus sceleratus (Gmelin, 1789) in the Eastern Mediterranean. GCP/INT/041/EC - GRE - ITA/TDFVX-10. Athens 2012: 39 pp.,

Nikolsky, G.V. (1963). The ecology of fishes (Transelated from Russian) Academic press. London-New York.

Oral, M. (2010). Alien Fish Species in the Mediterranean - Black Sea Basin. J. Black Sea/ Medit. Envir., 16(1): 87-132

Oso, J. A.; Idowu, E. O.; Fagbuaro, O.; Olaniran, T. S. and Ayorinde, B. E. (2011). Fecundity, Condition Factor and Gonado-Somatic Index of HepsetusOdoe (African 
Pike) in a Tropical Reservoir, Southwest Nigeria. World J. Fish and Mari. Sci., 3 (2): 112-116.

Peristeraki, P.; Lazarakis, G.; Skarvelis, C.; Georgiadis, M and Tserpes, G. (2006). Additional records on the occurrence of alien fish species in the eastern Mediterranean Sea. Medit. Mar. Sci., 7(2): 61-66

Peristeraki, P.; Lazarakis, G. and Tserpes, G. (2010). First results on the maturity of the lessepsian migrant Lagocephalus sceleratus (Gmelin, 1789) in the eastern Mediterranean Sea. Rapp. Comm. Int. MerMédit., 39: 629pp.

Pitt, T. K. (1970): Distribution, abundance and spawning of yellow-pale flounder Limanda ferruginae in the new founland area of the north-west Atlantic. J. Fish. Res., Bd. Can., 27(12): 2261-2271.

Plaza, G.; Sakaji, H.; Honda, H.; Hirota, Y. and Nashida, K. (2007): Spawning pattern and type of fecundity in relation to ovarian allometry in the round herring Etrumeus teres. Mar. Biol., 152:1051-1064.

Pyper, B. J.; Peterman, R. M.; Lapointe, M. F. and Walters, C. J. (1999). Patterns of covariation in length and age at maturity of British Columbia and Alaska sockeye salmon (Oncorhynchus nerka) stocks. Canad. J. Fish. Aquat. Sci., 56: 1046-1057.

Rousou, M.; Ganias, K.; Kletou, D.; Loucaides, A. and Tsinganis, M. (2014).Maturity of the pufferfish Lagocephalus sceleratus in the southeastern Mediterranean Sea. Sex. Early Develop. Aquat. Organisms, 1: 35- 44.

Saborida-Rey, F. and Junquera, S. (1998). Histological assessment of variations in sexual maturity of cod (Gadusmorhua L.) at the Flemish Cap (north-west Atlantic).ICES J.Mar. Sci., 55: 515-521.

Sabrah, M. M., El-Ganainy, A. A. and Zaky, M. A. (2006). Biology and toxicity of the pufferfish Lagocephalus sceleratus (Gmelin, 1789) from the Gulf of Suez. Egypt. J. Aquat. Res., 32(1): 283-279.

Schmitt, C.C. and Skud, B.E. (1978).Relation of fecundity to long-term changes in growth, abundance and recruitment. Internat. Pacific Halibut Commi, Scient. Rep., 66. $31 \mathrm{p}$.

Snedecor, G. W. (1956). Statistical methods applied to experiments in agriculture and biology. The low state University Press, U. S. A., 534 pp.

Sokal, R. R. and Rohlf, F. J. (1969). Biometry Freeman and Company, San Francisco, Ca, 776pp.

Statistica, (2007). Statsoft-Inc for Windows Release, U.S.A.

Wallace, R. A. and Selman, K. (1981). Cellular and dynamic aspects of oocyte size in teleosts. Am Zool., 21:325-343.

White, D. B.; Wyanski, D. M. and Sedberry, G. R. (1998). Age, growth, and reproductive biology of the blackbelly rosefish from the Carolinas, U.S.A. J. Fish Biol., 53:1274-1291.

Yoshida, M. O. (1966). Skipjack Tuna spawning in the Marquesas Island and Tuamotu Archipelago. Bull. Fish., 65(2): 479 - 488.

Zaki, M. I., Negm, R. K., El-Agamy, A. and Awad, G. S. (2005). Ultrastructure of male germ cell and character of spermatozoa in Boopsboops (family sparidae) in Alexanria coast, Egypt. Egypt. J. Aquat. Res., 31 (2): 293-313. 